\title{
Laminoplasty using the Posterior Midline Approach in the Treatment of C1-2 Spinal Tumors
}

\author{
C1-2 Spinal Tümörlerin Tedavisinde Posterior Orta Hat Yaklaşımı \\ Kullanularak Laminoplasti
}

Chang-Shun BAO, Fu-Bing YANG, Liang LIU, Bing WANG, Xiang-Guo XIA, Li-Gang CHEN

The Affiliated Hospital of Luzhou Medical College, Department of Neurosurgery, Luzhou, China

Corresponding Author: Li-Gang CHEN / E-mail: changshunbaocn@163.com

\begin{abstract}
AIM: This study aimed to investigate the method and efficacy of vertebral reconstruction using the posterior midline approach (PMA) in the treatment of C1-2 spinal tumors.

MATERIAL and METHODS: Twenty-seven patients with C1-2 spinal tumors from the Affiliated Hospital of Luzhou Medical College, who underwent microsurgical tumor resection through an occipitocervical PMA and spinal reset-reconstruction from January 2007 to December 2013, were enrolled in the study. The clinical data and results of these patients were analyzed and summarized.

RESULTS: All patients underwent a successful complete tumor resection, with no operative deaths. The postoperative pathological diagnoses were schwannoma, neurofibroma, and meningioma in 21,1 , and 5 cases, respectively. The follow-up period was $4-48$ months. Postoperatively, 1 patient was independent in daily activities, and 26 patients were able to live and work normally. No significant change was found between preoperative and postoperative MRI sequences of the cervical spine, and no cervical instability and tumor recurrence had occurred.

CONCLUSION: PMA is suitable as the preferred approach for resection of C1-2 spinal tumors, and the vertebral reconstruction maintains spinal stability.
\end{abstract}

KEYWORDS: Posterior midline approach, Laminoplasty, Spinal tumors, Cervical vertebra

ÖZ

AMAÇ: Çalışma C1-2 spinal tümörlerin tedavisinde posterior orta hat yaklaşımı (PMA) kullanılarak vertebral rekonstrüksiyonun yöntem ve etkinliğini incelemeyi amaçlamıştır.

YÖNTEM ve GEREÇLER: Çalışmaya Luzhou Tıp Fakültesi Hastanesinde Ocak 2007 ile Aralık 2013 arasında, C1-2 spinal tümör tanısı ile oksipitoservikal PMA yoluyla mikrocerrahi tümör rezeksiyonu ve spinal reset-rekonstrüksiyonu yapılan 27 hasta kaydedilmiştir. Bu hastaların klinik verileri ve sonuçları analiz edilip, özetlenmiştir.

BULGULAR: Tüm hastalarda başarılı tümör rezeksiyonu yapılmış ve operatif ölüm olmamıştır. Postoperatif patolojik tanı sırasıyla 21, 1 ve 5 olguda schwannom, nörofibrom ve menenjiyom olmuştur. Takip süresi 4-48 aydır. Postoperatif olarak 1 hasta günlük aktivitelerde bağımsız ve 26 hasta normal şekilde yaşar ve çalışır duruma gelmiştir. Preoperatif ve postoperatif servikal omurga MRG sekansları arasında önemli bir değişiklik görülmemiş ve herhangi bir servikal stabilite problemi ve tümör nüksü oluşmamıştır.

SONUÇ: PMA, C1-2 spinal tümörlerin rezeksiyonu için tercih edilen yaklaşım olarak uygundur ve vertebral rekonstrüksiyon spinal stabiliteyi sürdürür.

ANAHTAR SÖZCÜKLER: Posterior orta hat yaklaşımı, Laminoplasti, Spinal tümörler, Servikal vertebra

\section{INTRODUCTION}

C1-2 spinal tumors are generally localized at the foramen magnum or occipito-cervical junction zone, with some arising from nasopharyngeal carcinoma (23), although there is a possibility that a synovial cyst may be misdiagnosed as a tumor (11). In addition to the complications involved in the diagnosis of these tumors, they could cause compression of the cervical spinal cord and medulla oblongata because of their closeness to these structures, causing respiratory and circulatory disorders, as well as tetraplegia. Previous studies have reported a characteristic spinal cord deformity and paralysis due to the tumor compression-induced atlantoaxial rotation in some patients (17). In addition, this tumor can also lead to death. As the surgery required is difficult and involves high-risk, the general agreement is that the surgical approach should be decided based on the specific location and the extent of tumor invasion. The various approaches include posterior, posterolateral, anterior, and anterolateral. When a posterior approach is not possible, a posterolateral approach is used, especially in the treatment of posterior cranial fossa (6). In order to maintain the cervical spine alignment 
postoperatively, all open surgeries have to be performed with the least invasive surgical approach for stripping the C2 spinous paraspinal muscles (25). Particularly, approaches that emphasize the importance of rebuilding the spinal structure and function, such as semi-laminectomy, full laminectomyrest-fixation, and full laminectomy-bone graft-internal fixation-fusion, are used commonly. A previous foreign study reported the gamma knife treatment to be safe with a small postoperative tumor residual (27). However, even though high level spinal tumors have been clinically studied for many years, there is a considerable number of patients who exhibit postoperative spinal cord compression, infection, wound leakage, and other complications, which seriously affect the patients' quality of life. In order to further explore the surgical treatment of high level spinal tumors, the tumor incidence, clinical manifestations, imaging characteristics, surgical methods, and results were comprehensively reviewed in 27 patients who were recently admitted to the Hospital of Luzhou Medical College for treatment of C1-2 spinal tumors.

\section{MATERIAL and METHODS}

\section{Patients}

Twenty-seven patients [15 men, 12 women; mean age, 42.5 years (age range, 12-69 years)] from the affiliated Hospital of Luzhou Medical College, who underwent microsurgical resection of C1-2 spinal tumors using the occipitocervical PMA from January 2007 to December 2013, were enrolled in the study. The average disease duration was 10.5 months (range, 2 months -3 years).

\section{Surgery}

Preoperative preparation: The preoperative CTA and MRI images were carefully reviewed to determine the location and extent of tumor invasion, whether the tumor extended to the intervertebral foramen, the displacement degree of the compressed spinal cord, walking directions of vertebral arteries, whether the vertebral arteries were compressed and tortuous, as well as the relationship between tumor tissues and other spinal nerves; these factors were important considerations for determining the intraoperative laminectomy scope and for reducing the incidence of injury to the spinal cord, nerve roots, and vertebral arteries.

Surgical technique: The patient received general anesthesia with endotracheal intubation in the prone position; a " $U$ "shaped pillow was used to support the chest and abdomen, while the head was fixed to the head frame. The skin and subcutaneous tissues were cut through a PMA, and the edge of foramen magnum, atlantoaxial posterior arch, spinous process, and lamina were fully revealed. The resection ranges of the occipital bone and lamina were as follows: 1) if the upper edge of the tumor exceeded the foramen magnum, the appropriate occipital squama was cut off to form an occipital bone window; 2 ) if the upper edge of tumor did not exceed the foramen magnum, there was generally no need to resect the occipital bone; grinding the atlantoaxial posterior arch would be adequate, (Figure $1 \mathrm{~A}-\mathrm{F}$ ); 3 ) if the lower edge of tumor did not exceed the upper edge of $\mathrm{C} 2$, or it exceeded but did not extend to $1 / 3$ of the upper vertebral body, just milling the atlantoaxial posterior arch was considered adequate, and a resection of $\mathrm{C} 2$ spinous process base would be performed, if necessary; 4) if the lower edge of the tumor exceeded $1 / 3$ of the upper C2 vertebral body, both the spinous process and lamina had to be milled (Figure 2A-F); the endorachis was cut and suspended, and the tumor capsule was carefully separated microscopically followed by removal of the tumor. The dentate ligaments and $\mathrm{C} 1$ or $\mathrm{C} 2$ nerve root was cut when necessary; when the tumor was large or adherent and not easily separated from the dura, the resection could be done plate by palate. In the case of a dumbbell-shaped tumor, the outer portion of the spinal cord, which would include tumors in the isthmus and those processed outside the spinal cord, could be resected first to avoid injury to the vertebral arteries, and then the tumors inside the spinal cord would be resected, so that the dural sac and the cerebrospinal fluid would serve as buffers to protect the spinal cord. After the tumor resection, the dura was sutured tightly. As resection of the dumbbell-shaped tumor would usually result in a large dural defect, dural repair is required in order to prevent cerebrospinal fluid leakage and adhesions between the spinal cord and surrounding tissues. The miniature titanium screws (Shanghai Tiema Medical Apparatus Co. Ltd, ShangHai, China) and titanium plates (Shanghai Tiema Medical Apparatus Co. Ltd, ShangHai, China) were used to reset and fix the lamina after the atlantoaxial posterior arch and axis were milled, then performed the spinal reconstruction (Figure $2 A-F$ ). The muscles and ligaments were then sutured layer by layer to achieve anatomical reduction, with the conventional epidural drainage tube in place.

\section{RESULTS}

\section{Clinical Manifestations}

One of the 27 patients had no nerve damage and spinal cord compression because of the small size of the tumor. The symptoms presented by the remaining 26 patients were neck pain (19 cases), limb numbness and decreased muscle strength (13 cases), decreased limb muscle strength (7 cases), physical pain, numbness, and hypoalgesia (5 cases), active biceps and triceps reflexes (10 cases), hyperactive reflexes and Achilles tendon reflexes (7 cases), positive patellar and ankle clonus (5 cases), and positive Hoffmann sign and Babinski sign (12 cases).

\section{Imaging Data}

The preoperative X-ray and $\mathrm{CT}$ data revealed cervical degenerative changes in 10 patients, with 2 cases exhibiting curved impression changes in the curvature and vertebral bone resorption, with no obvious cervical instability. The MRI examination revealed that there were 8 cases of a dumbbellshaped mass that was isointense in T1WI and hyperintense in T2WI, and accompanied by lateral intervertebral foramen dilatation; 19 cases had an extramedullary subdural round or oval mass with clear boundaries, demonstrating isointensity 

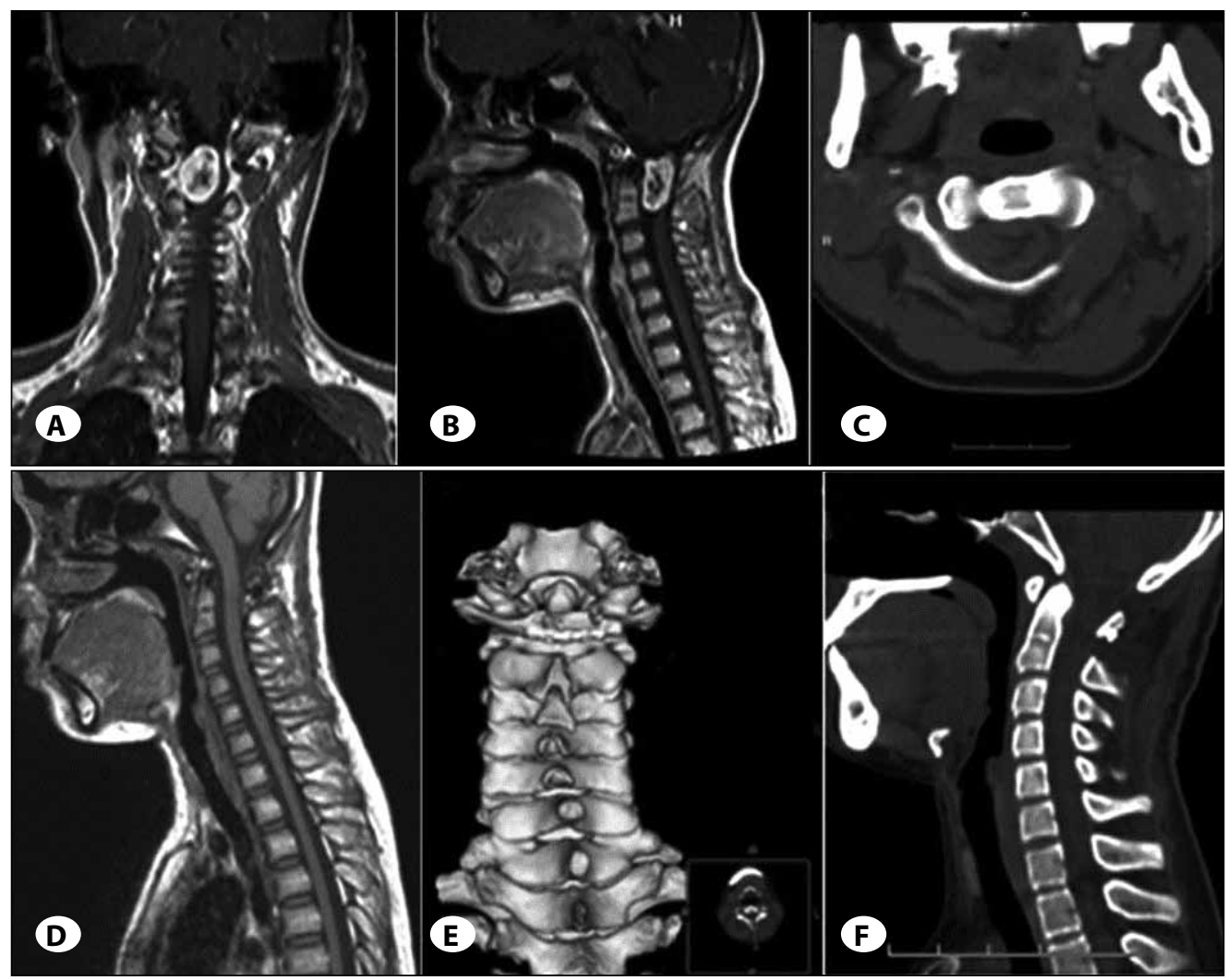

Figure 1: Radiographical findings of intraduralextramedullary tumor. Preoperative A) coronal, B) sagittal MR and C) axial CT images. Postoperative D) sagittal MR and

E) 3-dimensional and F) sagittal CT images.

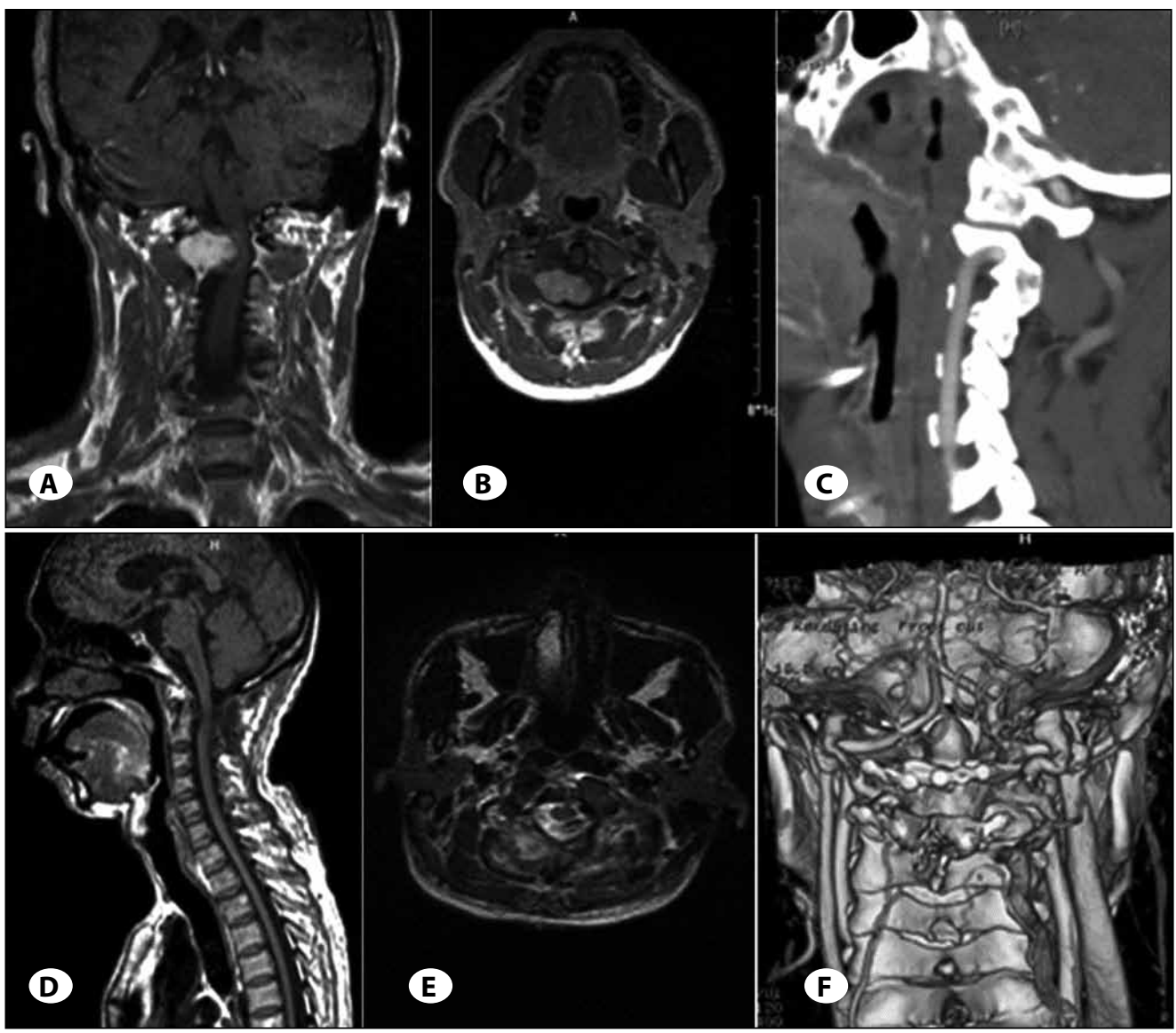

Figure 2: Radiographical findings of intraduralextramedullary tumor. Preoperative A) coronal, B) axial MR and C) sagittal CT images. Postoperative D) sagittal, E) axial MR and F) 3-dimensional CT images. 
on T1WI and hyperintensity on T2WI, with the upper cervical cord compressed and exhibiting displacement; 4 cases had a tumor on the ventral side of the cervical cord; 7 cases had a tumor in the anterior lateral of the cervical cord; 10 cases had a tumor in the posterior aspect of the cervical cord; and in 6 cases, the tumor was located in the posterior lateral part of the cervical cord.

\section{Surgical Outcome and Pathological Diagnosis}

All the tumors in this group were fully resected, and there were no deaths. The pathological diagnoses were as follows: 21 cases of schwannoma, 1 case of neurofibroma, and 5 cases of meningioma.

\section{Short-Term Follow-Up}

The postoperative review exhibited no significant changes between the preoperative and postoperative cervical sequences, and no cervical instability was noted.

\section{Long-Term Follow-Up}

The mean follow-up period was 24.2 (4-48) months. Among the patients, a 68-year-old male patient (with history of 14 years of hypertension, 8 years of diabetes, carried the cardiac defibrillators preoperatively to eliminate the arrhythmia) exhibited a good postoperative response; however, he experienced a sudden onset of suffocation on postoperative day 3 , which resulted in a coma. After rescue measures including tracheotomy were performed, he regained consciousness on the next day, but with decreased muscle strength (grade 4) in the upper limbs and grade 3 in the lower extremities). Following neurotrophic therapy and vascular activation, he experienced cerebrospinal fluid leakage at the wound site on postoperative day 18. Continuous drainage of lumbar cisterna cerebellomedullaris was performed, and the wound healed 10 days later; the patient was discharged 2 months after the surgery with complete recovery of the lower extremity muscle strength to grade 5; he was able to carry out his daily activities and live a normal life after 6 months. Among the remaining 26 patients, there were 4 cases of decreased single lateral limb muscle strength, who showed a gradual recovery after 6 months, and 3 cases of single lateral upper arm and neck hypoesthesia; these patients recovered gradually during the follow-up. All 26 patients returned to normal living and work, with no tumor recurrence.

\section{DISCUSSION}

C1-2 spinal tumors generally occur as localized tumors at the foramen magnum or occipital-cervical junction zone. In a previous report, George has reported that C1-2 spinal tumors account for approximately $5 \%$ of all spinal tumors and $18 \%$ of cervical spinal tumors (8). According to Maurya, C1 and C2 nerve root tumors account for $13.2 \%$ of all spinal nerve root tumors and $30.2 \%$ cervical nerve root tumors (15), whereas in Ozawa's study, C1-2 spinal tumors accounted for $14.4 \%$ of all spinal tumors and $39.5 \%$ of cervical spinal tumors (16). Krishnan reported that the C1-2 spinal tumors accounted for $5 \%-12 \%$ of all spinal nerve root tumors and $18 \%-30 \%$ of all cervical nerve root tumors (14). Our hospital enrolled 27 cases of C1-2 spinal tumors from January 2007 to December 2013, accounting for $32.9 \%$ of all cervical spinal tumors $(27 / 82)$ and $9.8 \%$ of all spinal tumors (27/315); the incidence in our hospital was similar to that reported in the above-mentioned literature.

The spinal canal at C1-2 is larger than that at the lower cervical spine levels, and there was no spinal cord swelling, the tumor at this site has more space available as it grows in size and the onset of symptoms is delayed; the tumor size is therefore large at the time of diagnosis in most cases. The purpose of surgical intervention was to remove the tumor, relieve the tumor-caused oppression of the spinal cord, and restore the normal spinal cord functions. In the case of the dumbbell-shaped tumor that grows outside the spinal cord, it is removed to avoid tumor recurrence (12).

The surgical approach selection for C1-2 spinal tumors depends upon the tumor size and location, as well as the surgeon's experience. The common surgical approaches are the far lateral transcondylar, anterior, and posterior approaches $(2,5,15)$. The PMA is the most commonly used approach, and it is the one that most neurosurgeons are familiar with; it is therefore the preferred approach for C1-2 spinal tumors $(3,15,24)$. PMA is advantageous in that it allows easier access or easy viewing of the tumor, and involves a small degree of trauma, shorter operative time, less blood loss, low infection probability, and easier spinal reconstruction. There is consensus among foreign and domestic clinicians that PMA is the ideal approach for tumors located in the dorsal and the lateral rear aspects of the spinal cord $(3,8,12,14,15,24)$. Even in the case of the dumbbell-shaped tumor, this approach fully reveals the area within $3 \mathrm{~cm}$ of the outer edge of the dural sac; the tumor can therefore be removed completely in the vast majority of cases (1). For tumors on the ventral or lateral aspects of the front of the spine, the use of this approach is controversial. Some clinicians have suggested use of the anterior approach (5), so that the tumors could be resected after subtotal resection of the front vertebral body. However, the anterior approach involves greater surgical trauma, longer time, deeper operating fields, and smaller view, the operation chance to remove the tumor was small, which often causes vertebral venous plexus bleeding. Additionally, there was a significant intraoperative interference by the spinal cord, which increased the postoperative symptoms and risk of developing postoperative infection $(12,14)$. Some surgeons have used the far lateral approach, which may lead to less nerve damage (20) but longer time to mastery; this approach allows the easy viewing of the tumor reveal, protects the vertebral artery, and provides access to the tumor boundary in the front of the myelencephalon-neck junction under direct vision (2); however, the surrounding tissue structure with this approach is very complex and requires extensive resection of bones and soft tissues, with a great extent of intraoperative damage. Moreover, the domestic neurosurgeons were not familiar with this approach, and therefore, it could not be applied clinically. Also, all of the approaches are associated 
with difficulties in spinal stability after reconstruction (5). While hemilaminectomy maybe another option for intraspinal tumor which lead to better spinal stability (26), it was rarely chosen in rural hospitals because of limited experience. Though PMA is associated with certain risks in cases of tumor invasion from the lateral side of the cervical spinal cord to the front of the cervical spinal cord, the small articular process can be resected during the surgery (4), and the dentate ligaments can be cut, or if necessary, the C1-C2 nerve roots could be cut. And in some developing countries, PMA maybe the most common approach for spinal surgery. Following the steps, when the spinal cord is retracted gently, a better surgical field can be obtained for the revealing and removal of the tumors, as confirmed by both foreign and domestic clinicians $(1,14,22)$. In the case of the dumbbellshaped tumor, intra-decompression should be performed first, followed by intradural tumor resection. The spinal arachnoid space remains intact; thus, the buffer effect of the cerebrospinal fluid can be used to avoid traction injury of the spinal cord. Intraoperatively, microscopic tumor resection and neuroelectrical physiological detection could possibly minimize spinal cord injury. We believe that if the anatomical characteristics of the cervical spine, preoperative tumor size, as well as the relationship between the tumor and the spinal cord, are understood well, this together with a carefully performed surgery would enable total resection of the C1-2 spinal tumor by PMA without any serious interference by the spinal cord $(1,14,20,22)$.

The course of the vertebral artery at $\mathrm{C} 1$ and $\mathrm{C} 2$ sites is complex, which poses a challenge with respect to a complete view and resection of the tumor (especially the dumbbellshaped tumor). The pure extramedullary subdural tumors would generally not be affected by this, but because the dumbbell-shaped tumor often invades the area surrounding the vertebral artery, the intraoperative protection would be especially important in its case. During the surgery, we realized that the vertebral artery was surrounded by the venous plexus and most tumors have their own capsules, even though a close relationship between the vertebral artery and tumors is displayed on images. As there are gaps between tumors and vertebral arteries, a careful microscopic surgery, during which tumor resection is strictly restricted to within the capsule, would enable completely stripping of the tumor $(1,10)$.

C1-2 spinal tumors are mostly schwannomas, generally originating from the dorsal spinal nerve root. Jinnai reported that of 176 spinal nerve sheath tumors, 170 tumors originated from the rear spinal nerve root, and 6 originated from the front spinal nerve root (13). In this study, the tumor in 22 cases originated from the spinal nerve root (22 cases of schwannoma and 1 case of neurofibroma), accounting for $77.8 \%$ of the tumors, and all were derived from the posterior nerve root. It has been reported in literature that $\mathrm{C} 1$ and C2 nerve roots are relatively "non-functional", and that they exhibit an imbricated distribution on the surface of high cervical spinal nerves; cutting of 1 or 2 unilateral spinal nerve roots would usually not cause significant neurological dysfunction (7). Therefore, when dealing with the tumor located along the ventral aspect of the spinal cord, one could consider cutting the $\mathrm{C} 1$ and $\mathrm{C} 2$ posterior nerve roots, so that the tumor could be easily viewed and removed under direct vision. However, if the nerve is found to be adherent to tumor surface intraoperatively, we should first try to separate the two carefully to avoid the emergence of new postoperative neurological deficits. In the case of a tumor-bearing nerve that is difficult to separate, it could be removed along with the tumor. In this study, in order to fully reveal the surgical field, 2 C1 nerve roots and 3 C2 nerve roots were cut, and 3 tumorbearing nerves were resected with the tumors because of the difficulty encountered in separating them. Four patients demonstrated transient, minor occipitocervical hypoesthesia postoperatively.

C1 and C2 play an extremely important role in the activity and stability of the neck, and resection of the cervical body and articular process is one of the common causes of cervical instability; it is also the primary reason for development of goose neck deformity and delayed spinal cord injury. Many clinicians believe that the reconstruction of cervical spine instability is an important aspect of high cervical spinal tumor treatment $(12,18,24)$. According to Goel, because C2 schwannomas are in most cases located at the ganglion and are subdural, and because they are located between the atlas and atlantoaxial joint, as well as inside the atlantoaxial joint, resection of the atlantoaxial posterior arch and vertebral body to fully expose and remove the tumor is not required (9). In this group of patients, we found that the C1-2 spinal bodies were wider, and the average sagittal diameter was 20-23 $\mathrm{mm}$ (14). In the case of the extramedullary epidural tumors, resection of the atlantoaxial posterior arch and/or vertebral spinous process could fully reveal and enable complete removal of the tumor, which generally would not affect the small joints on the side of the tumor. Sometimes, in order to expose the ventral spinal cord tumors, some small joints could be resected. Because there is no intervertebral foramen between the atlas and occiput, as well as between the atlas and axis, the $\mathrm{C} 1$ and $\mathrm{C} 2$ nerve roots extend out of the vertebral body from the upper edge of the atlantoaxial posterior arch and from the atlantoaxial vertebral body; so, the resection of dumbbell-shaped tumor would generally not involve the small joints on the side of the tumor. For 3 patients in this study, a portion of the atlantoaxial joint was cut to fully reveal the ventral spinal cord tumors. Although a literature review showed no advantage of laminoplasty than laminectomy in 2003 (19), we still found that during the postoperative followup in our study, these patients exhibited no spinal instability occurrence. In order to preserve postoperative activity and stability of the cervical spine, all patients in this group underwent laminoplasty, which would not only restore the integrity of the spinal canal but also prevented scar formation and kyphosis deformity-caused compression of the spinal cord. The number of cases in this group was small and the follow-up was short; a long-term follow up with a larger sample size is required to further investigate the effect of laminoplasty on spinal stability. 


\section{ACKNOWLEDGEMENTS}

This study was conducted in accordance with the declaration of Helsinki. This study was conducted with approval from the ethics committee of Luzhou Medical College.

\section{REFERENCES}

1. Angevine PD, Kellner C, Haque RM, McCormick PC: Surgical management of ventral intradural spinal lesions. J Neurosurg Spine 15: 28-37, 2011

2. Banerji D, Behari S, Jain VK, Pandey T, Chhabra DK: Extreme lateral transcondylar approach to the skull base. Neurol India 47: 22-30, 1999

3. Barami K, Dagnew E: Endoscope-assisted posterior approach for the resection of ventral intradural spinal cord tumors: Report of two cases. Minim Invasive Neurosurg 50: 370-373, 2007

4. Bartolomei JC, Crockard HA: Bilateral posterolateral approach to mirror-image C-2 neurofibromas. Report of four cases. J Neurosurg 94: 292-298, 2001

5. Behari S, Banerji D, Trivedi P, Jain VK, Chhabra DK: Anterior retropharyngeal approach to the upper cervical spine. Neurol India 49: 342-349, 2001

6. Benet A, Prevedello DM, Carrau RL, Rincon-Torroella J, Fernandez-Miranda JC, Prats-Galino A, Kassam AB: Comparative analysis of the transcranial "far lateral" and endoscopic endonasal "far medial" approaches: Surgical anatomy and clinical illustration. World Neurosurg 81: 385396,2014

7. Celli P: Treatment of relevant nerve roots involved in nerve sheath tumors: Removal or Preservation? Neurosurgery 51: 684-692; discussion 692, 2002

8. George B, Lot G: Neurinomas of the first two cervical nerve roots: A series of 42 cases. J Neurosurg 82: 917-923, 1995

9. Goel A, Muzumdar D, Nadkarni T, Desai K, Dange N, Chagla $A$ : Retrospective analysis of peripheral nerve sheath tumors of the second cervical nerve root in 60 surgically treated patients. J Neurosurg Spine 8: 129-134, 2008

10. Gu YF, Li YD, Wu CG, Sun ZK, He CJ: Safety and efficacy of percutaneous vertebroplasty and interventional tumor removal for metastatic spinal tumors and malignant vertebral compression fractures. AJR Am J Roentgenol 202: W298-W305, 2014

11. Harries A, Wasserberg J: Synovial cyst presenting as a $C 1 / 2$ tumour. Br J Neurosurg 24: 595-596, 2010

12. Hirano K, Imagama S, Sato K, Kato F, Yukawa Y, Yoshihara $H$, Kamiya M, Deguchi M, Kanemura T, Matsubara $Y$, Inoh H, Kawakami N, Takatsu T, Ito Z, Wakao N, Ando K, Tauchi R, Muramoto A, Matsuyama $\mathrm{Y}$, Ishiguro N: Primary spinal cord tumors: Review of 678 surgically treated patients in Japan. A multicenter study. Eur Spine J 21: 2019-2026, 2012
13. Jinnai $\mathrm{T}$, Koyama $\mathrm{T}$ : Clinical characteristics of spinal nerve sheath tumors: Analysis of 149 cases. Neurosurgery 56: 510515; discussion 510-515, 2005

14. Krishnan P, Behari S, Banerji D, Mehrotra N, Chhabra DK, Jain VK: Surgical approach to C1-C2 nerve sheath tumors. Neurol India 52: 319-324, 2004

15. Maurya P, Singh K, Sharma V: $C 1$ and $C 2$ nerve sheath tumors: Analysis of 32 cases. Neurol India 57: 31-35, 2009

16. Ozawa H, Kokubun S, Aizawa T, Hoshikawa T, Kawahara C: Spinal dumbbell tumors: An analysis of a series of 118 cases. $J$ Neurosurg Spine 7: 587-593, 2007

17. Ozawa $H$, Kusakabe $T$, Aizawa T, Nakamura T, Ishii $Y$, Itoi E: Tumors at the lateral portion of the C1-2 interlaminar space compressing the spinal cord by rotation of the atlantoaxial joint: New aspects of spinal cord compression. J Neurosurg Spine 17: 552-555, 2012

18. Ramme AJ, Smucker JD: Balancing spinal stability and future mobility in the cervical spine: Surgical treatment of a case of osteoblastoma with secondary aneurysmal bone cyst. Spine J 11: e5-e12, 2011

19. Ratliff JK, Cooper PR: Cervical laminoplasty: A critical review. J Neurosurg 98 Suppl 3: 230-238, 2003

20. Refai D, Shin JH, lannotti C, Benzel EC: Dorsal approaches to intradural extramedullary tumors of the craniovertebral junction. J Craniovert Jun Spine 1: 49-54, 2010

21. Seckin H, Ates O, Bauer AM, Baskaya MK: Microsurgical anatomy of the posterior spinal artery via a far-lateral transcondylar approach. J Neurosurg Spine 3: 228-233, 2009

22. Singh SK, Rickards L, Apfelbaum RI, Hurlbert RJ, Maiman D, Fehlings MG: Occipitocervical reconstruction with the Ohio Medical Instruments Loop: Results of a multicenter evaluation in 30 cases. J Neurosurg 98: 239-246, 2003

23. Tiruchelvarayan $\mathrm{R}$, Lee $\mathrm{KA}, \mathrm{Ng}$ I: Surgery for atlanto-axial (C12) involvement or instability in nasopharyngeal carcinoma patients. Singapore Med J 53: 416-421, 2012

24. Wang Y, Lou PY, Li M: Clinical features and surgical procedures of intradural-epidural and epidural cervical dumbbell tumors. Chin Med J (Engl) 126: 2797-2798, 2013

25. Watanabe $M$, Sakai D, Yamamoto $Y$, Iwashina T, Sato $M$, Mochida J: Upper cervical spinal cord tumors: Review of 13 cases. J Orthop Sci 14: 175-181, 2009

26. Xie T, Qian J, Lu Y, Chen B, Jiang Y, Luo C: Biomechanical comparison of laminectomy, hemilaminectomy and a new minimally invasive approach in the surgical treatment of multilevel cervical intradural tumour: A finite element analysis. Eur Spine J 12: 2719-2730, 2013

27. Zenonos G, Kondziolka D, Flickinger JC, Gardner P, Lunsford LD: Gamma Knife surgery in the treatment paradigm for foramen magnum meningiomas. J Neurosurg 117: 864-873, 2012 